\title{
Michel Touret, Blaise Cendrars: le désir du roman (1920-1930)
}

\section{Emanuele Kanceff}

\section{Q OpenEdition}

1 Journals

\section{Edizione digitale}

URL: https://journals.openedition.org/studifrancesi/41107

DOI: 10.4000/studifrancesi.41107

ISSN: 2421-5856

\section{Editore}

Rosenberg \& Sellier

\section{Edizione cartacea}

Data di pubblicazione: 1 juillet 2004

Paginazione: 218

ISSN: 0039-2944

\section{Notizia bibliografica digitale}

Emanuele Kanceff, «Michel Touret, Blaise Cendrars: le désir du roman (1920-1930)», Studi Francesi

[Online], 142 (XLVIII | I) | 2004, online dal 30 novembre 2015, consultato il 09 septembre 2021. URL: http://journals.openedition.org/studifrancesi/41107; DOI: https://doi.org/10.4000/studifrancesi. 41107

Questo documento è stato generato automaticamente il 9 septembre 2021.

\section{(c)}

Studi Francesi è distribuita con Licenza Creative Commons Attribuzione - Non commerciale - Non opere derivate 4.0 Internazionale. 


\title{
Michel Touret, Blaise Cendrars: le désir du roman (1920-1930)
}

\author{
Emanuele Kanceff
}

\section{NOTIZIA}

MICHEL TOURET, Blaise Cendrars: le désir du roman (1920-1930), Paris, Honoré Champion

Éditeur, 1999, pp. 408 («Cahiers Blaise Cendrars», 6).

1 Nato nel 1887, Cendrars aveva 27 anni quando, nell'agosto del 1914, si arruolò volontario, un anno dopo la pubblicazione della Prose du Transsibérien. Tornato dal fronte profondamente segnato nel fisico, lo scrittore sembra trasformarsi e gli anni Venti vedono uscire, uno dopo l'altro, una serie cospicua di romanzi, mentre altre attività, edizione, cinema, reportage, viaggi, politica, vengono a confermare la trasformazione in atto. Questo cammino verso una apparente facilità e dispersione fu il prezzo pagato - sostiene l'autore - perché l'esperienza romanzesca potesse giungere a una scrittura assolutamente nuova e personale. È tale metamorfosi che l'autore analizza finemente, situandone l'origine nel senso di esclusione di cui il poeta soffre nel dopoguerra.

2 Entrare nel romanzo, genere allora in crisi, significa scegliere una forma in cui tutto è possibile, libera e senza costrizioni formali; significa anche adottare una posizione in cui la scrittura non è più funzione del solo individuo ma in rapporto stretto con il mondo reale, dell'esperienza e della conoscenza; significa entrare in un dominio in cui la letteratura affronta la realtà esterna, la descrive, la giudica, la mette in discussione. Ciò corrisponde bene alla condizione profetica e aristocratica dello scrittore, elaborata fin dagli anni di gioventù da Blaise Cendrars. 